Article

\title{
The Economic-Environmental Impacts of China's Action Plan for Soil Pollution Control
}

\author{
Zhitao Li ${ }^{1,2}$, Xiahui Wang ${ }^{1, *}$, Jia Li ${ }^{3}$, Wei Zhang ${ }^{4, *}$, Ruiping Liu ${ }^{1}$, Zhixiao Song ${ }^{1}$, \\ Guoxin Huang ${ }^{1}$ and Linglong Meng ${ }^{1}$ \\ 1 Soil Environmental Protection Center, Chinese Academy for Environmental Planning, Beijing 100012, China; \\ lizt@caep.org.cn (Z.L.); liurp@caep.org.cn (R.L.); songzx@caep.org.cn (Z.S.); huanggx@caep.org.cn (G.H.); \\ mengll@caep.org.cn (L.M.) \\ 2 School of Environmental Science and Engineering, Tianjin University, Tianjin 300072, China \\ 3 International Center for Environmental Technology, International Environmental Cooperation Center, \\ Ministry of Ecology and Environment, Beijing 100035, China; li.jia@iecomee.org.cn \\ 4 State Environmental Protection Key Laboratory of Environmental Planning and Policy Simulation, Chinese \\ Academy for Environmental Planning, Beijing 100012, China \\ * Correspondence: wangxh@caep.org.cn (X.W.); zhangwei@caep.org.cn (W.Z.)
}

Received: 25 March 2019; Accepted: 12 April 2019; Published: 17 April 2019

\begin{abstract}
To effectively control soil pollution, an action plan (called Soil Plan) was carried out by Chinese government in 2016, which may cost CNY 1.14 trillion during the 2016-2020 period. To evaluate the potential impacts of this action plan on the national economy and environmental control, this study employed a closed macro input-output model to quantitatively account for the economic and environmental impacts from the view of the whole domestic supply chain. Our results show that the implementation of the Soil Plan may stimulate economic development and bring more jobs. It will help generate a gross domestic product (GDP) of CNY 2.72 trillion, with CNY 358.11 billion (15\%) made from direct contributions, and CNY 2.36 trillion $(85 \%)$ from indirect contributions. Meanwhile, the scheme could also produce 2 million jobs within five years, of which 580,000 (29\%) are a direct contribution, and 1.42 million (71\%) are an indirect contribution. On the other hands, increased demands for products and services of various sectors (such as power/heat production and supply, and chemical products) would also cause more air and water pollutants along with domestic supply chains. The emissions of sulfur dioxide $\left(\mathrm{SO}_{2}\right)$, nitrogen oxide $\left(\mathrm{NO}_{\mathrm{x}}\right)$, chemical oxygen demand (COD) and ammonia nitrogen $\left(\mathrm{NH}_{3}-\mathrm{N}\right)$ would increase by a total of $5.20 \times 10^{5} \mathrm{t}, 5.27 \times 10^{5} \mathrm{t}, 1.62 \times$ $10^{5} \mathrm{t}$ and $9.36 \times 10^{3} \mathrm{t}$, respectively. Our results may raise the concern about the indirect impacts of an environmental policy for the policy maker from both economic and environmental perspectives.
\end{abstract}

Keywords: Soil Plan; input-output model; economic impact; environmental impact

\section{Introduction}

Soil plays a fundamental role in the functioning of the ecosystem; it is, therefore, critical to ensure the health of soil [1]. However, the soil has been seriously polluted in many parts of the world, and recent estimates suggest that in some parts of China's agricultural soil has been contaminated by heavy metals [2]. According to the latest findings of the national survey on soil quality, $16.1 \%$ of all samples taken nationwide exceeded healthy levels of metal pollution, with $19.4 \%$ of samples taken from agricultural areas exceeding the standards, the main pollutants being $\mathrm{Cd}, \mathrm{Ni}, \mathrm{Cu}, \mathrm{As}, \mathrm{Hg}, \mathrm{Pb}$, DDT and PAHs [3]. Over the last few decades, many surveys of this kind have been carried out in China, including in the North China Plain, the Pearl River Delta, the Yangtze River Basin, and South China. They have shown agricultural soil in China to be suffering from heavy metal pollution [4]. 
Soil pollution not only affects the quality of the soil environment, but also poses a threat to food security, human health and ecological environments [5]. Soil pollution has become a hot topic, with many pollution incidents reported by the media, such as high Cd levels being found in rice, and "contaminated land" [6,7]. Meanwhile, the itai-itai disease caused by $\mathrm{Cd}$ poisoning has already broken out among some villages in Hunan Province [8]. It is an urgent requirement, therefore, to implement measures to reduce the risk of soil pollution.

In May 2016, the State Council of China issued the Action Plan for Prevention and Control of Soil Pollution (Soil Plan) to effectively control soil pollution and gradually improve soil quality. The Action Plan pledged to make about $90 \%$ of polluted arable land and over $90 \%$ of polluted sites safe for human use by 2020, with an increase to both over $95 \%$ by 2030 [9]. Ten special measures have been drafted alongside the Soil Plan to ensure the fulfillment of these targets. A total of CNY 1.14 trillion is expected to be invested during the 5-year scheme (2016-2020).

The implementation of the Soil Plan requires a huge investment, which aims to improve China's soil quality, but also promotes the development of soil pollution control-related sectors, boosting the macroeconomic system through the upstream and downstream supply chains $[10,11]$. Therefore, a scientific evaluation of the social and economic impact of the Soil Plan can assist industrial planners and environmental practitioners in scientific decision making. Meanwhile, during the Soil Plan, rising demands for products and services (such as power and steel) will inevitably lead to the use of more natural resources and generate pollutants, which poses environment issues [12]. Therefore, the impact of the Soil Plan on the emission of pollutants should be scientifically evaluated.

The input-output model is a quantitative economic analysis method with which the technical and economic relationship between different sectors of the national economy, as well as each step of reproduction, can be scientifically analyzed against an input-output table [12]. This model has been widely applied to analyze the impacts of large-scale infrastructure investment, the government economic stimulus plan, and environmental protection investments on the macroeconomy $[13,14]$. Economists have also used the model to analyze the effectiveness of environmental investments made in an attempt to fuel the economy [15-17]. Additionally, resources and environmental input-output can also be simulated by inputting industrial pollution emissions and resource consumption data into the model, and evaluating the impact of environmental protection investment on resource consumption and emissions [12].

In this study, a closed macro input-output model mapping the spillover and linkage effects of industrial and residential consumption was established to quantitatively evaluate the impacts of the Soil Plan on China's economy. Meanwhile, the impact of the Soil Plan on employment within different sectors was also quantitatively simulated. In addition, an environmental input-output model was established to evaluate the impact of the Soil Plan on emissions.

\section{Methodology and Data}

\subsection{Environmentally Extended Input-Output Framework}

First developed by Leontief in 1970, the input-output model has been widely used across different fields: economic analyses, policy simulations, plan argumentation and economic forecasts [10,18-21]. The calculations of economic impacts and emission contributions are based on environmentally extended input-output (IO) analysis. This well established method is the basis of the System of National Accounts and is well suited to the analysis of the economic and environmental Impacts of the massive investment induced by Soil Plan. The 2015 China Monetary Input-Output Table, published by China's National Bureau of Statistics, was used as the input-output (IO) table for the present study. Table 1 shows the structure of this IO table, which consists of 42 sectors (listed in Appendix A, Table A1). 
Table 1. The structure of China monetary input-output table used in this study.

\begin{tabular}{|c|c|c|c|c|c|c|c|c|c|}
\hline \multirow[b]{2}{*}{ Input } & \multirow[b]{2}{*}{ Output } & \multicolumn{3}{|c|}{ Intermediate Use } & \multicolumn{3}{|c|}{ Final Use } & \multirow[b]{2}{*}{ Imports } & \multirow{2}{*}{$\begin{array}{l}\text { Total } \\
\text { Output }\end{array}$} \\
\hline & & Sector 1 & $\ldots$ & $\begin{array}{l}\text { Sector } \\
42\end{array}$ & $\begin{array}{c}\text { Final } \\
\text { Consumption }\end{array}$ & $\begin{array}{l}\text { Capital } \\
\text { Formation }\end{array}$ & Exports & & \\
\hline $\begin{array}{l}\text { Intermediate } \\
\text { inputs }\end{array}$ & $\begin{array}{c}\text { Sector } 1 \\
\ldots \\
\text { Sector } 42\end{array}$ & & $\mathrm{X}_{i j}$ & & & $\mathrm{Y}_{j}$ & & $\mathrm{IM}_{j}$ & $\mathrm{X}_{i}$ \\
\hline Value added & $\begin{array}{l}\text { Employee } \\
\text { compensation } \\
\text { Net taxes on } \\
\text { production } \\
\text { Depreciation } \\
\text { of fixed } \\
\text { capital } \\
\text { Operating } \\
\text { surplus }\end{array}$ & & $\mathrm{G}_{i j}$ & & & & & & \\
\hline Total & aputs & & $\mathrm{X}_{j}$ & & & & & & \\
\hline
\end{tabular}

Assuming that $a_{i j}, x_{i}, x_{j}$ and $y_{i}$ represent the direct consumption coefficient, column vector and row vector of total output, and column vector of final demand, respectively, a transverse equation of input-output can be established as:

$$
\sum a_{i j} \cdot x_{j}+y_{i}=x_{i}
$$

Equation (1) could be further expressed as a matrix equation:

$$
X=(I-A)^{-1} Y
$$

where the vector $X(\mathrm{n} \times 1$ column) indicates each sector's total output (in RMB); the vector $Y(\mathrm{n} \times 1$ column) indicates each sector's final demand; and the $n \times n$ matrix $(I-A)^{-1}$ is Leontief inverse matrix, which reflects the underlying relationship between final demand and total output. Changes in final demand $(\Delta Y)$ would lead to changes in total output $(\Delta X)[22]$, written as:

$$
\Delta X=(I-A)^{-1} \Delta Y
$$

The Soil Plan's investment projects were further divided into fixed capital formation and the consumption of goods and services, and classified according to different sectors. A column vector $\left(\Delta Y_{e}\right)$ was then obtained and added into Equation (3).

$$
\Delta X=(I-A)^{-1} \Delta Y_{e}
$$

More final demands resulting from investment during the Soil Plan leads to a rise in residents' consumption (income), again boosting various production sectors of China's national economy [23]. However, the growth in residents' income cannot be completely converted into local investment and consumption, due to savings, taxes, and imports-resulting in economic leakage. Therefore, it is necessary to establish a closed macro input-output model, excluding the impact of consumption growth and economic leakage. Using the derivation path proposed by previous research [24], the equation below can be obtained:

$$
\Delta X=(I-A)^{-1}\left(I-C(1-t) \hat{h} F i, \hat{W}(I-A)^{-1}\right)^{-1} \Delta Y_{e}
$$

$C$ represents the marginal propensity to consume (to deduct the effect of consumption leakage); $t$ represents the marginal propensity to tax (to deduct the effects of tax paid); $\hat{h}$ represents the diagonal matrix of domestic availability rates of final products (to deduct the effects of import leakage); $F$ represents the column vector of residents' direct consumption coefficients, $i^{\prime}$ represents the unit row vector, and $\hat{W}$ represents the diagonal matrix of compensation coefficients. The domestic availability 
rates of final products illustrate the proportion of domestic products to final products in various sectors; residents' direct consumption coefficients refer to the proportion of residents' consumption in various sectors to residents' total consumption; and compensation coefficients refer to coefficients of compensation in various sectors divided by total output.

Economic impact evaluation. Adding a row vector of economic growth coefficients $(\hat{G})$ and a row vector of input coefficients of labor force $(\hat{J})$ into Equation (5), GDP growth $(\Delta G)$ and employment positions $(\Delta J)$ can be described respectively as:

$$
\begin{gathered}
\Delta G=\hat{G} \Delta X \\
\Delta J=\hat{J} \Delta X
\end{gathered}
$$

The economic growth coefficient for a sector is the ratio of economic growth to total output; the input coefficient of the labor force for a sector is the ratio of employment positions to total output. The economic growth of all sectors can be directly obtained from the third quadrant of the input-output table. All the employment data has been taken from the 2017 China Labour Statistical Yearbook [25].

Environmental impact evaluation. Adding a row vector of emission intensity $(\hat{S})$ into Equation (5), the growth in emissions $(\Delta S)$ of typical pollutants $\left(\mathrm{SO}_{2}, \mathrm{NO}_{\mathrm{x}}, \mathrm{COD}\right.$ and $\left.\mathrm{NH}_{3}-\mathrm{N}\right)$ can be described as:

$$
\Delta S=\hat{S} \Delta X
$$

Emission data of these four typical pollutants across various sectors were taken from the 2015 China Environmental Statistics [26].

\subsection{Data Sources}

Investment of the Soil Plan: Investment data for the Soil Plan was taken from the Table of Funding Estimates for the Soil Plan. As shown in Table 2, the Soil Plan's investment will be categorized into four main fields, namely, fundamental capacity building, soil pollution risk management and control, soil pollution treatment and remediation, and soil pollution source control. A total of CNY 1.14 trillion

\begin{tabular}{|c|c|c|c|}
\hline No. & Aspect & Details & $\begin{array}{l}\text { Investment } \\
\text { Amount } \\
\text { (Billion Yuan) }\end{array}$ \\
\hline A & $\begin{array}{l}\text { Fundamental } \\
\text { capacity building }\end{array}$ & $\begin{array}{c}\text { A detailed survey on soil pollution; revision of laws, regulations, relevant } \\
\text { standards and technical specifications; capacity building for soil monitoring and } \\
\text { law enforcement; construction of soil pollution control laboratories and } \\
\text { engineering technology centers }\end{array}$ & 72.50 \\
\hline B & $\begin{array}{l}\text { Risk management } \\
\text { and control }\end{array}$ & $\begin{array}{c}\text { Safe utilization measures (agricultural regulation, alternative planting, etc. for } \\
\text { slightly polluted farmland); risk control measures (planting structure adjustment, } \\
\text { returning farmland to forest or grassland etc.) for seriously polluted farmland; } \\
\text { barrier and enclosure etc. for contaminated sites }\end{array}$ & 321.00 \\
\hline $\mathrm{C}$ & $\begin{array}{l}\text { Pollution } \\
\text { treatment and } \\
\text { remediation }\end{array}$ & $\begin{array}{l}\text { Pilot and demonstration of pollution management and remediation; construction } \\
\text { of pilot areas of soil pollution management; management and remediation of } \\
\text { contaminated farmland }\end{array}$ & 179.00 \\
\hline \multirow[t]{2}{*}{$\mathrm{D}$} & $\begin{array}{l}\text { Pollution source } \\
\text { control }\end{array}$ & $\begin{array}{l}\text { Heavy metal pollution prevention and remediation; comprehensive control and } \\
\text { treatment of tailings ponds, solid waste dumps and informal landfills; } \\
\text { construction of pilot areas for collaborative control and treatment }\end{array}$ & 569.52 \\
\hline & & Total & 1142.02 \\
\hline
\end{tabular}
will be invested during the period 2016-2020.

Table 2. Investment of the Soil Plan.

Investment direction data: The investment sums for these four main fields should be re-calculated to define the amount of investment in final products (goods and services) by sector, which would facilitate the evaluation of macroeconomic impact. Usually, a soil remediation project is composed of the following endeavours: survey design, equipment purchase, engineering management, scientific research and technical services. In the present study, the investment in the aforementioned four main 
fields was further segmented, merged, and then assigned to each sector in the input-output table, against investment expenditure data of several soil pollution control projects in Sichuan, Hunan, and Hubei provinces. The investment by sector was then summarized (Table 3), corresponding to $\Delta Y_{e}$ in the input-output model.

Table 3. Investment directions and their corresponding sectors of Soil Plan.

\begin{tabular}{|c|c|c|c|}
\hline Investment Direction & Corresponding Sectors & $\begin{array}{l}\text { Investment Amount } \\
\text { (Billion Yuan) }\end{array}$ & $\begin{array}{l}\text { Proportion } \\
\text { (Billion Yuan) }\end{array}$ \\
\hline $\begin{array}{l}\text { Investigation and } \\
\text { assessment on soil pollution; } \\
\text { law and regulation making }\end{array}$ & $\begin{array}{l}\text { Scientific researches and } \\
\text { technical services }\end{array}$ & 28.76 & $28.76(\mathrm{~A})$ \\
\hline $\begin{array}{l}\text { Purchase of equipment } \\
\text { solely for environmental } \\
\text { protection, e.g., rapid } \\
\text { monitoring equipment for } \\
\text { contaminated land, etc. }\end{array}$ & $\begin{array}{l}\text { Special-purpose equipment } \\
\text { manufacturing }\end{array}$ & 26.92 & $26.92(\mathrm{~A})$ \\
\hline $\begin{array}{l}\text { Architectural engineering; } \\
\text { installation and debugging }\end{array}$ & Construction & 582.34 & $\begin{array}{l}50.00(\mathrm{~B})+50.00 \\
(\mathrm{C})+482.34(\mathrm{D})\end{array}$ \\
\hline $\begin{array}{l}\text { Purchase of general } \\
\text { equipment, including } \\
\text { pile-turning machine and } \\
\text { sieving-crushing bucket etc. }\end{array}$ & $\begin{array}{l}\text { General equipment } \\
\text { manufacturing }\end{array}$ & 252.35 & $\begin{array}{c}150.00(B)+50.00 \\
(C)+52.35(D)\end{array}$ \\
\hline $\begin{array}{l}\text { Purchase of seeds and } \\
\text { afforestation, etc. }\end{array}$ & $\begin{array}{l}\text { Products and services of } \\
\text { agriculture, forestry, animal } \\
\text { husbandry and fishery }\end{array}$ & 225.73 & $\begin{array}{c}120.00(B)+78.26 \\
(C)+27.47(D)\end{array}$ \\
\hline $\begin{array}{c}\text { Development of } \\
\text { environmental information } \\
\text { management platforms }\end{array}$ & $\begin{array}{l}\text { Information dissemination, } \\
\text { software and IT services }\end{array}$ & 0.79 & $0.79(\mathrm{~A})$ \\
\hline $\begin{array}{l}\text { Scientific experimental } \\
\text { research; engineering } \\
\text { exploration, design and } \\
\text { management services }\end{array}$ & $\begin{array}{l}\text { Scientific research and } \\
\text { technical services }\end{array}$ & 23.73 & $\begin{array}{l}16.03 \text { (B) }+7.70 \\
\text { (D) }\end{array}$ \\
\hline
\end{tabular}

Note: A, B, C, and D represent the four aspects in Table 1.

\section{Results}

\subsection{The Economic Impact of the Soil Plan}

As shown in Table 4, the CNY 1142 billion investments in the Soil Plan would help increase China's GDP by CNY 2716 billion over five years (2016 to 2020)—direct and indirect contributions making up CNY 358.11 billion and CNY 2358 billion, respectively. The input-output ratio of investment in the Soil Plan is 1:2.38, which means that each yuan investment of the Soil Plan would induce GDP of CNY 2.38. The 10 main sectors that benefit from investment of Soil Plan include Construction, Agriculture/forestry/animal husbandry/fishery, Transportation and warehousing, Wholesale and retail, Special-purpose equipment manufacturing, Finance, Oil and natural gas mining, Black metal smelting and rolling processing, Non-metal mineral products, as well as Comprehensive technical services. The induced GDP of these 10 sectors is CNY 1500 billion, which accounts for 55\% of the total induced GDP by the investment of Soil Plan. The GDP growth of the Construction and Special-purpose equipment manufacturing will be a direct contribution of the investment during the Soil Plan, whereas the growth of some basic sectors of the national economy-such as the Agriculture, forestry, animal husbandry and fishing, and Transportation and warehousing, will only be indirectly attributable to Soil Plan investments through industrial supply chains. 
Table 4. The economic impacts of the Soil Plan on gross domestic product (GDP) by sectors (units: billion yuan).

\begin{tabular}{ccccc}
\hline Sectors & Total Impacts & Direct Impacts & Indirect Impacts & Proportion (\%) \\
\hline Construction & 350.36 & 203.56 & 146.80 & 12.90 \\
Agriculture/forestry/animal husbandry/fishery & 168.39 & 0.00 & 168.39 & 6.20 \\
Transportation \& warehousing & 152.10 & 0.00 & 152.10 & 5.60 \\
Wholesale \& retail & 138.52 & 0.00 & 138.52 & 5.10 \\
Special-purpose equipment manufacturing & 171.11 & 107.87 & 63.24 & 6.30 \\
Finance & 124.94 & 0.00 & 124.94 & 4.60 \\
Oil and natural gas mining & 114.07 & 0.00 & 114.07 & 4.20 \\
Black metal smelting \& rolling processing & 103.21 & 0.00 & 103.21 & 3.80 \\
Non-metal mineral product & 93.70 & 0.00 & 93.70 & 3.45 \\
Comprehensive technical service & 84.20 & 18.78 & 65.42 & 3.10 \\
Others & 1215.41 & 27.90 & 1187.51 & 44.75 \\
Total & 2716.00 & 358.11 & 2357.89 & 100.00 \\
\hline
\end{tabular}

\subsection{Impacts of the Soil Plan on Employment}

As shown in Table $5,198 \times 10^{4}$ new jobs would be created over five years during the implementation of the Soil Plan. Among them, $62 \times 10^{4}$ jobs (31\%) would be a direct contribution, while $137 \times 10^{4}$ $(69 \%)$ jobs would be created indirectly. The 10 main sectors to benefit from the Soil Plan's investments would include Construction, Wholesale and retail, Transportation and warehousing, Special-purpose equipment manufacturing, Accommodation and catering, Non-metal mineral products, Residential and other services, Metal products, Clothing and textiles, and Agriculture, forestry, animal husbandry and fishing. These sectors alone would see the creation of $63 \times 10^{4}$ new jobs, accounting for $32 \%$ of total figures. The new jobs created for sectors such as Construction and Special-purpose equipment manufacturing would result from direct contribution, whilst the jobs created in other less labor-intensive sectors, such as the Wholesale retail, Accommodation and catering, and Residential services, would be categorized as an indirect contribution.

Table 5. The Soil Plan's impacts on employment by sectors (units: $\times 10^{4}$ jobs).

\begin{tabular}{ccccc}
\hline Sectors & Total Impacts & Direct Impacts & Indirect Impacts & Proportion (\%) \\
\hline Construction & 46 & 40 & 6 & 23.0 \\
Wholesale and retail & 27 & 0 & 27 & 13.7 \\
Transportation and warehousing & 17 & 4 & 13 & 8.4 \\
Special-purpose equipment manufacturing & 10 & 7 & 3 & 5.1 \\
Accommodation and catering & 9 & 0 & 9 & 3.6 \\
Non-metal mineral product & 7 & 0 & 7 & 3.6 \\
Residential services and other services & 6 & 0 & 6 & 2.6 \\
Metal products & 5 & 1 & 4 & 2.2 \\
Textile/clothing/shoes/hat making & 4 & 0 & 4 & 3.1 \\
Agriculture/forestry/animal husbandry/fishery & 4 & 0 & 4 & 100 \\
Others & 63 & 10 & 54 & 137 \\
Total & 198 & 62 & & \\
\hline
\end{tabular}

\subsection{The Impact of the Soil Plan on Main Pollutant Emissions}

More products and services would be used during the implementation of the Soil Plan. Using existing production technologies and processes, many more pollutants are sure to be released into the environment. For this reason, the impact of the Soil Plan on emissions of atmospheric and water pollutants was also calculated. The results are shown in Figures 1 and 2 below. 


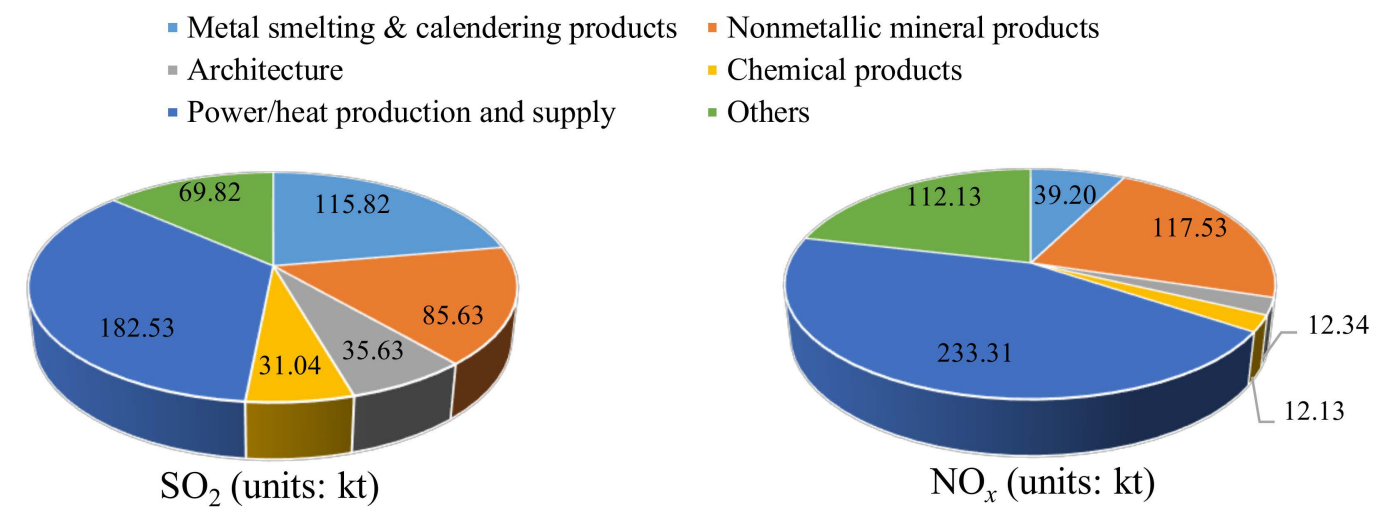

Figure 1. Emission of atmospheric pollutants $\left(\mathrm{SO}_{2}\right.$ and $\left.\mathrm{NO}_{x}\right)$ by sector.
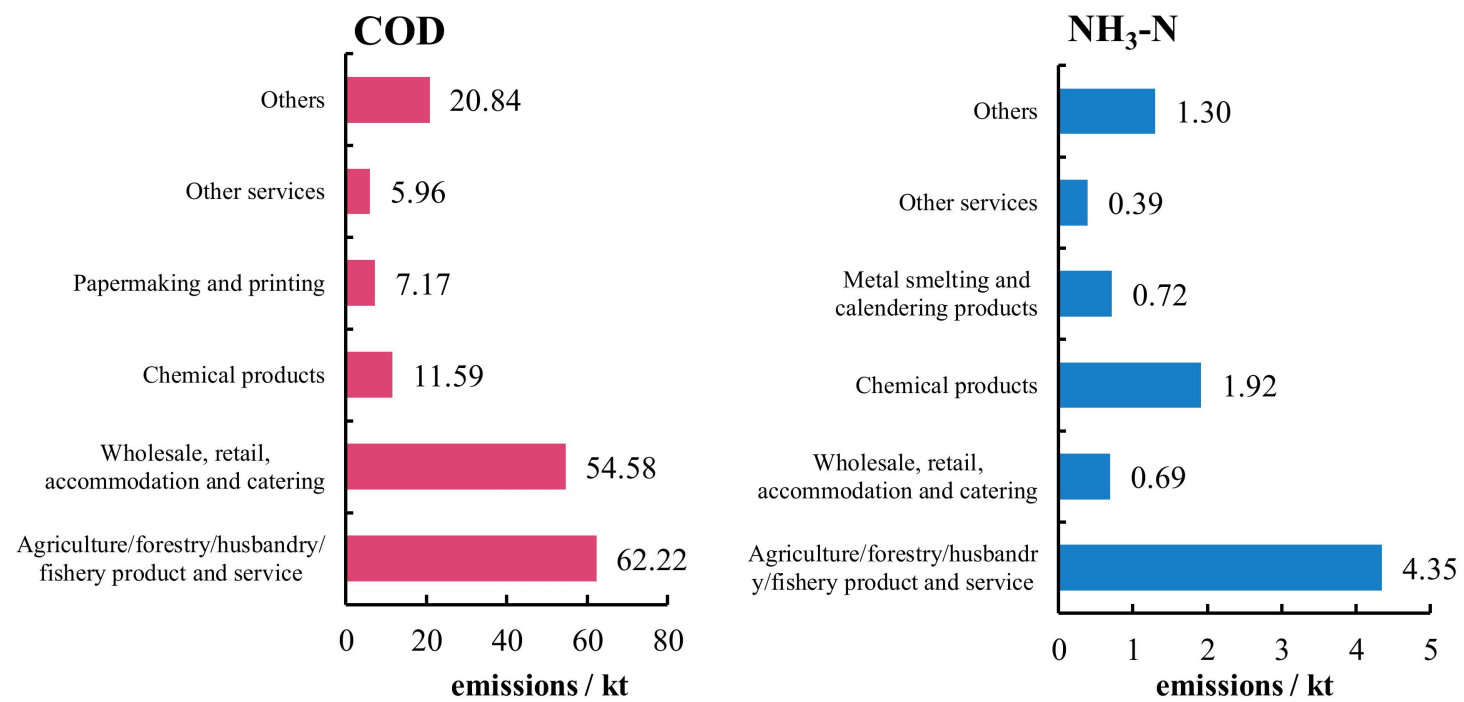

Figure 2. Emission of wastewater pollutants (COD and $\left.\mathrm{NH}_{3}-\mathrm{N}\right)$ by sector.

During the implementation of the Soil Plan, additional $\mathrm{SO}_{2}$ and $\mathrm{NO}_{x}$ emissions, amassing 5.20 $\times 10^{5} \mathrm{t}$ and $5.27 \times 10^{5} \mathrm{t}$, respectively, would be produced. Several sectors, such as production and supply of Electricity and heat, Metal smelting and calendering products, and Non-metallic mineral products caused more $\mathrm{SO}_{2}$ and $\mathrm{NO}_{x}$ emissions than others, accounting for $73.8 \%$ and $74.1 \%$ of total new emissions of each pollutant, respectively (Figure 1). As illustrated in the 2015 Bulletin of National Environmental Statistics [27], the amounts of emissions of $\mathrm{SO}_{2}$ and $\mathrm{NO}_{x}$ were $1859.1 \times 10^{4} \mathrm{t}$ and 1851.9 $\times 10^{4} \mathrm{t}$, respectively. During the implementation of the Soil Plan, additional $\mathrm{SO}_{2}$ and $\mathrm{NO}_{x}$ emissions associated with the Soil Plan were equivalent to $2.80 \%, 2.85 \%$ of yearly emissions in 2015, respectively. These statistics all pose serious ramifications for the atmospheric environment. Previous studies have found that environmental protection investment impacts the emission of pollutants. Zhang et al. [12] evaluated the potential environmental impacts of China's Action Plan on Prevention and Control of Air Pollution based on the environmental input-output model. The results showed that annual averages of new $\mathrm{SO}_{2}$ and $\mathrm{NO}_{x}$ emissions accounted for $3.8 \%$ and $2.2 \%$ of the expected emission reductions proposed by the Action Plan, respectively.

On the other hand, the release of potential water pollutants was also predicted to increase during the Soil Plan's implementation period, with emissions of $\mathrm{COD}$ and $\mathrm{NH}_{3}-\mathrm{N}$ rising by $1.62 \times 10^{5} \mathrm{t}$ and 9.36 $\times 10^{3} \mathrm{t}$, respectively. In addition, the Agriculture, forestry, animal husbandry and fishing, Wholesale and retail, and Chemical products contributed a total of $79.1 \%$ and $74.3 \%$ of new COD and $\mathrm{NH}_{3}-\mathrm{N}$ emissions, respectively (Figure 2). Moreover, the Metal smelting and calendering products would cause $0.72 \mathrm{kt}$ of new $\mathrm{NH}_{3}-\mathrm{N}$ emissions. As illustrated in the 2015 Bulletin of National Environmental Statistics [27], the amount of emissions of COD and $\mathrm{NH}_{3}-\mathrm{N}$ were $2223.5 \times 10^{4} \mathrm{t}$ and $229.9 \times 10^{4} \mathrm{t}$, 
respectively. During the implementation of the Soil Plan, new $\mathrm{COD}$ and $\mathrm{NH}_{3}-\mathrm{N}$ emissions were equivalent to $0.73 \%$ of yearly emissions in 2015 , respectively.

\section{Discussion}

\subsection{The Soil Plan's Main Investments and Associated Economic Impacts}

As shown in Table 3, of the CNY 582.3 billion investment in Construction, most investment would be used to renovate tailing reservoirs, solid waste storage and landfill sites. As by-products of mining and mine-processing activities, tailings are a mixture of sand, fine-grained solid materials, water and significant quantities of heavy metals [28]. Tailings are generally deposited in open-air tailing reservoirs without any treatment [29]. It was estimated that China had more than 12,000 tailing reservoirs, occupying a large expanse of land across the nation [30]. Tailing reservoirs are the main cause of acid mine drainage (AMD). AMD is easily produced after the oxidation of various sulfide minerals in tailings [31]. Featuring low $\mathrm{pH}$ value and a high concentration of toxic metals, AMD can seriously contaminate the surrounding environment [32]. Meanwhile, due to the aeolian transport of tailing sand, metal pollution can spill to soils of the adjacent agricultural and pasture land [33]. Solid waste storage and landfill sites can also contaminate adjacent areas and cause serious damage [34]. Therefore, efforts should be made to immediately reduce such environmental risks. A portion of the investment should also be used for isolating and retaining contaminated soil, preventing further expansion of polluted areas.

General equipment manufacturing would receive an investment of CNY 252.3 billion, for three main areas: purchase of general equipment in pollution prevention and control projects for tailing reservoirs, solid waste storage and landfill sites, and soil pollution rehabilitation projects. For soils of different pollution levels, different remediation strategies are laid out in the Soil Plan: for slightly contaminated soils, agronomy regulation and alternative planting can be used to ensure the soil's continued use as well as food safety; for heavily contaminated soil, adjustment of plant structures, and returning farmland to forest or grassland was suggested to reduce the migration of pollutants into the food chain. The implementation of these strategies would generate new demands for seeds, saplings and grass, as well as planting and afforestation services. Therefore, a total of CNY 225.73 billion would be invested in Agriculture, forestry, animal husbandry and fishing and services.

The launch of environmental protection projects and construction of related equipment would increase the demand for steel products and, therefore, facilitate the development of ferrous metals, smelting and calendering. Meanwhile, environmental protection projects are likely to use large quantities of stones, cement and other construction materials, thereby contributing to the development of non-metallic mineral products. During the implementation of the Soil Plan, the development of the ferrous metal smelting and calendering and non-metallic mineral products would contribute a GDP growth of CNY 103.21 billion and CNY 93.70 billion, respectively. In addition, the development of other sectors would also be boosted by the upstream and downstream supply chains. The Soil Plan's investments would also see the development of various other sectors, creating more jobs and a new basis for GDP growth. As a result of the Soil Plan's investments, China's GDP would grow by CNY 2.716 trillion and 2 million new jobs would be created over five years (2016-2020).

\subsection{Potential Environmental Impact and Risk of the Soil Plan}

The Soil Plan would increase the demand for products and services of various sectors, resulting in an increased consumption of resources and more emissions. Over the five years of its implementation, the Soil Plan would induce more atmospheric pollutants released into the environment, due to a huge consumption of power [12] - especially taking into account China's heavy reliance on thermal power. Meanwhile, ferrous metal smelting and calendering will lead to more atmospheric pollutants due to vast consumption of coal. During the Soil Plan, the power, heat production and supply, ferrous metal 
smelting and calendering would contribute new $\mathrm{SO}_{2}$ emissions of $1.83 \times 10^{5} \mathrm{t}$ and $1.16 \times 10^{5} \mathrm{t}$, and new $\mathrm{NO}_{\mathrm{x}}$ emissions of $2.33 \times 10^{5} \mathrm{t}$ and $1.18 \times 10^{5} \mathrm{t}$, respectively.

The Soil Plan will also lead to an increase in wastewater pollutants. The Agricultural sector accounted for $48.06 \%$ of total COD emissions, and 31.58\% $\mathrm{NH}_{3}-\mathrm{N}$ emissions. Nitrogenous fertilizers, livestock manure and other fertilizers used in the agricultural production process risk contaminating neighboring water bodies due to farmland runoff and sediment $[35,36]$. The Soil Plan will may consume more produce of Agriculture, forestry, animal husbandry, fishing and also likely to lead to higher emissions. The development of agriculture, meanwhile, is likely to result in greater demand for chemical products, such as fertilizers and pesticides; further promoting the development of chemical products. This will also lead to higher emissions according to the input-output model used in this research. During the Soil Plan, Agriculture, forestry, animal husbandry, fishing and service and Chemical products would contribute new COD emissions of $6.22 \times 10^{4} \mathrm{t}$ and $1.16 \times 10^{4} \mathrm{t}$, and new $\mathrm{NH}_{3}-\mathrm{N}$ emissions of $4.35 \times 10^{3} \mathrm{t}$ and $1.92 \times 10^{3} \mathrm{t}$, respectively.

Greater demands for more products and services from various sectors, which are likely to accompany the Soil Plan, will lead to higher emissions. There are also similar examples in other fields. Previous research shows that the production of olives needs more than $90 \%$ of non-renewable energy requirements throughout the whole production chain [37]. It may pose health threats to those residing in those areas. Therefore, more efforts should be made to promote technological advancements and industrial revamps for an accelerated circular economy, and clean production in key sectors [38]. This may need greener supply chains to minimize negative environmental impact the Soil Plan [39].

\subsection{Limitation and Future Directions}

In this study, a closed macro input-output model was used to simulate the economic impact of the Soil Plan's investment. Our results were based on the following assumptions: (1) the Soil Plan's investments would be solely used for the consumption of products, and that all projects undertaken during the Soil Plan would be implemented as originally planned; (2) industrial production technologies will remain unchanged between 2016 and 2020. The second assumption is a defect of the input-output model, as the simulation results will not reflect the impact of the technical advancements on future environmental protection activities. Therefore, it is recommended that the dynamic input-output model is used in future studies to improve prediction accuracy.

It is important that the Soil Plan is primarily used as a means of improving China's soil environmental quality. Economic and environmental concerns, therefore, should not be the primary concern of investments. Furthermore, investment differs by region, as do the industrial structures of each individual province and city. Further study is needed to assess the economic and environmental impacts of investment in different regions. This would help provide appropriate policy recommendations for environmental protection in local regions.

\section{Conclusions}

The Soil Plan will play a significant role in the improvement of China's soil quality and the development of the economy. During the implementation period (2016-2020), the Soil Plan is predicted to lead to a GDP growth of CNY 2.7 trillion, creating 2 million new jobs. In terms of GDP, those sectors most likely benefit from Soil Plan's implementation include Construction, Agriculture, forestry, animal husbandry, fishing, Transportation and warehousing, Wholesale and retail, and Special-purpose equipment manufacturing. The Soil Plan will give a direct impetus to the development of relevant sectors, such as Construction and Debugging, environmental protection equipment manufacturing and comprehensive technical services. This will answer the demands of emerging environmental protection. However, with more demands for products and services within various sectors (such as the power, heat and chemical products), emissions of typical atmospheric and wastewater pollutants such as $\mathrm{SO}_{2}, \mathrm{NO}_{\mathrm{x}}, \mathrm{COD}$ and $\mathrm{NH}_{3}-\mathrm{N}$ will also rise, with potentially serious environmental ramifications. 
Therefore, energy efficiency and pollution control must be improved across a range of sectors in order to reduce potential environmental impacts incurred by the Soil Plan.

Author Contributions: Conceptualization, Z.L., X.W. and W.Z.; methodology, Z.L. and W.Z.; validation, R.L. and Z.S.; formal analysis, Z.L.; resources, J.L. and G.H.; data curation, L.M.; writing-original draft preparation, Z.L. and J.L.; writing-review and editing, Z.L., X.W. and W.Z.; visualization, R.L. and W.Z.; supervision, X.W. and W.Z.; project administration, Z.L. and W.Z.; funding acquisition, X.W.

Funding: This work was supported by the National Key R\&D Program of China (Grant 2018YFC1800205) and the National Science Foundation of China (Grants 71603097, 71433007).

Conflicts of Interest: The authors declare no conflict of interest.

\section{Appendix A}

Table A1. The sectors in China's input-output table.

\begin{tabular}{|c|c|c|c|}
\hline & Sectors & & Sectors \\
\hline 1 & Agriculture, Forestry, Animal Husbandry and Fishery & 22 & Other manufacturing \\
\hline 2 & Mining and washing of coal & 23 & Comprehensive use of waste resources \\
\hline 3 & Extraction of petroleum and natural gas & 24 & Repair of metal products, machinery and equipment \\
\hline 4 & Mining and processing of metal ores & 25 & $\begin{array}{c}\text { Production and distribution of electric power and } \\
\text { heat power }\end{array}$ \\
\hline 5 & Mining and processing of nonmetal and other ores & 26 & Production and distribution of gas \\
\hline 6 & Food and tobacco processing & 27 & Production and distribution of tap water \\
\hline 7 & Textile & 28 & Construction \\
\hline 8 & Manufacture of leather, fur, feather and related products & 29 & Wholesale and retail trades \\
\hline 9 & Processing of timber and furniture & 30 & Transport, storage, and postal services \\
\hline 10 & $\begin{array}{l}\text { Manufacture of paper, printing and articles for culture, } \\
\text { education and sport activity }\end{array}$ & 31 & Accommodation and catering \\
\hline 11 & Processing of petroleum, coking, processing of nuclear fuel & 32 & $\begin{array}{l}\text { Information transfer, software and information } \\
\text { technology services }\end{array}$ \\
\hline 12 & Manufacture of chemical products & 33 & Finance \\
\hline 13 & Manufacture of non-metallic mineral products & 34 & Real estate \\
\hline 14 & Smelting and processing of metals & 35 & Leasing and commercial services \\
\hline 15 & Manufacture of metal products & 36 & Scientific research and polytechnic services \\
\hline 16 & Manufacture of general purpose machinery & 37 & $\begin{array}{l}\text { Administration of water, environment, and public } \\
\text { facilities }\end{array}$ \\
\hline 17 & Manufacture of special purpose machinery & 38 & Resident, repair and other services \\
\hline 18 & Manufacture of transport equipment & 39 & Education \\
\hline 19 & Manufacture of electrical machinery and equipment & 40 & Health care and social work \\
\hline 20 & $\begin{array}{l}\text { Manufacture of communication equipment, computers } \\
\text { and other electronic equipment }\end{array}$ & 41 & Culture, sports, and entertainment \\
\hline 21 & Manufacture of measuring instruments & 42 & $\begin{array}{c}\text { Public administration, social insurance, and social } \\
\text { organizations }\end{array}$ \\
\hline
\end{tabular}

\section{References}

1. Coppolecchia, D.; Puglisi, E.; Vasileiadis, S.; Suciu, N.; Hamon, R.; Beone, G.M.; Trevisan, M. Relative sensitivity of different soil biological properties to zinc. Soil Biol. Biochem. 2011, 43, 1798-1807. [CrossRef]

2. Li, J.; Ma, Y.B.; Hu, H.W.; Wang, J.T.; Liu, Y.R.; He, J.Z. Field-based evidence for consistent responses of bacterial communities to copper contamination in two contrasting agricultural soils. Front. Microbiol. 2015, 6, 31. [CrossRef] [PubMed]

3. Ministry of Ecology and Environment of PRC. The Nationwide Survey Communique of Soil Pollution. Available online: http://www.gov.cn/foot/site1/20140417/782bcb88840814ba158d01.pdf (accessed on 12 April 2019).

4. Du, P.; Xie, Y.; Wang, S.; Zhao, H.; Zhang, Z.; Wu, B.; Li, F. Potential sources of and ecological risks from heavy metals in agricultural soils, Daye City, China. Environ. Sci. Pollut. Res. 2015, 22, 3498-3507. [CrossRef] [PubMed]

5. Li, Z.; Ma, Z.; van der Kuijp, T.J.; Yuan, Z.; Huang, L. A review of soil heavy metal pollution from mines in China: Pollution and health risk assessment. Sci. Total Environ. 2014, 468, 843-853. [PubMed] 
6. Li, X.; Jiao, W.; Xiao, R.; Chen, W.; Chang, A. Soil pollution and site remediation policies in China: A review. Environ. Rev. 2015, 23, 263-274. [CrossRef]

7. Liu, X.; Tian, G.; Jiang, D.; Zhang, C.; Kong, L. Cadmium (Cd) distribution and contamination in Chinese paddy soils on national scale. Environ. Sci. Pollut. Res. 2016, 23, 17941-17952. [CrossRef] [PubMed]

8. Zhang, L. Absorption and Accumulation of Cadmium in Rice Intercropped by Echinodorus Osiris and the Change of Plant Rhizophere Soil Physicochemical Property; Guangxi University: Guangxi, China, 2013.

9. Zhang, F.; Li, G. China released the action plan on prevention and control of soil pollution. Front. Environ. Sci. Eng. 2016, 10, 19.

10. Miller, R.E.; Blair, P.D. Input-Output Analysis: Foundations and Extensions; Cambridge University Press: Cambridge, UK, 2009.

11. Pasurka, C.A., Jr. The short-run impact of environmental protection costs on US product prices. J. Environ. Econ. Manag. 1984, 11, 380-390. [CrossRef]

12. Zhang, W.; Wang, J.; Jiang, H.; Lei, Y.; Bi, J. Potential economy and environment impacts of China's National Air Pollution Control Action Plan. Res. Environ. Sci. 2015, 28, 1-7.

13. Jiang, H. The Principle and Contribution Models of Environment Protection Investment on Economic. Syst. Eng. Theory Pract. 2014, 24, 8-12.

14. Yang, Y. Effect of 2008 Olympic Games on Beijing Economy. China Sport Sci. 2005, 25, 3-6.

15. Jiang, H.; Cao, D.; Wagn, J.; Guo, X. The study on action principle of environmental protection investment on national economy and the contribution models. Res. Environ. Sci. 2005, 18, 71-74.

16. Li, L.; Lu, H.; He, S. Contribution of the environmental protection activity of Dianchi Lake Basin to GDP measured through green input-output table. Syst. Eng. Theory Pract. 2002, 9, 121-127.

17. Zhang, W.; Wang, J.; Zhang, B.; Bi, J.; Jiang, H. Can China comply with its 12th five-year plan on industrial emissions control: A structural decomposition analysis. Environ. Sci. Technol. 2015, 49, 4816-4824. [CrossRef] [PubMed]

18. Dietzenbacher, E.; Los, B. Structural decomposition techniques: Sense and sensitivity. Econ. Syst. Res. 1998, 10, 307-324. [CrossRef]

19. Hoekstra, R.; Van den Bergh, J.C. Constructing physical input-output tables for environmental modeling and accounting: Framework and illustrations. Ecol. Econ. 2006, 59, 375-393. [CrossRef]

20. Llop, M. Economic structure and pollution intensity within the environmental input-output framework. Energy Policy 2007, 35, 3410-3417. [CrossRef]

21. Rose, A.; Casler, S. Input-output structural decomposition analysis: A critical appraisal. Econ. Syst. Res. 1996, 8, 33-62. [CrossRef]

22. Liu, Q.; Cheng, W. Macroeconomic Forecasting and Planning; China Commodity Price Press: Beijing, China, 1998.

23. Peng, Z.; Qi, S. Multiplier analysis on the national economy. Stat. Res. 1998, 5, 49-53.

24. Liu, B. Analysis of input-output multipliers. Stat. Res. 1999, 5, 55-58.

25. China National Bureau of Statistics. China Labour Statistical Yearbook 2017; China Statistics Press: Beijing, China, 2018.

26. Ministry of Ecology and Environment of PRC. China Environmental Statistics Yearbook 2010; China Statistics Press: Beijing, China, 2012.

27. Ministry of Ecology and Environment of PRC. Bulletin of National Environmental Statistics in 2015; China Statistics Press: Beijing, China, 2017.

28. Santibañez, C.; de la Fuente, L.M.; Bustamante, E.; Silva, S.; León-Lobos, P.; Ginocchio, R. Potential use of organic-and hard-rock mine wastes on aided phytostabilization of large-scale mine tailings under semiarid Mediterranean climatic conditions: Short-term field study. Appl. Environ. Soil Sci. 2012, 2012. [CrossRef]

29. Wang, L.; Ji, B.; Hu, Y.; Liu, R.; Sun, W. A review on in situ phytoremediation of mine tailings. Chemosphere 2017, 184, 594-600. [CrossRef] [PubMed]

30. Yin, G.; Li, G.; Wei, Z.; Wan, L.; Shui, G.; Jing, X. Stability analysis of a copper tailings dam via laboratory model tests: A Chinese case study. Miner. Eng. 2011, 24, 122-130. [CrossRef]

31. Shu, X.-H.; Zhang, Q.; Lu, G.-N.; Yi, X.-Y.; Dang, Z. Pollution characteristics and assessment of sulfide tailings from the Dabaoshan Mine, China. Int. Biodeter. Biodegrad. 2018, 128, 122-128. [CrossRef]

32. Lefticariu, L.; Walters, E.R.; Pugh, C.W.; Bender, K.S. Sulfate reducing bioreactor dependence on organic substrates for remediation of coal-generated acid mine drainage: Field experiments. Appl. Geochem. 2015, 63, 70-82. [CrossRef] 
33. Rodríguez, L.; Gómez, R.; Sánchez, V.; Villaseñor, J.; Alonso-Azcárate, J. Performance of waste-based amendments to reduce metal release from mine tailings: One-year leaching behaviour. J. Environ. Manag. 2018, 209, 1-8. [CrossRef] [PubMed]

34. Sharholy, M.; Ahmad, K.; Mahmood, G.; Trivedi, R. Municipal solid waste management in Indian cities-A review. Waste Manag. 2008, 28, 459-467. [CrossRef]

35. Borin, M.; Bonaiti, G.; Giardini, L. Controlled drainage and wetlands to reduce agricultural pollution. J. Environ. Qual. 2001, 30, 1330-1340. [CrossRef]

36. Elias, D.; Wang, L.; Jacinthe, P.-A. A meta-analysis of pesticide loss in runoff under conventional tillage and no-till management. Environ. Monit. Assess. 2018, 190, 79. [CrossRef]

37. Cappelletti, G.M.; Ioppolo, G.; Nicoletti, G.M.; Russo, C. Energy requirement of extra virgin olive oil production. Sustainability 2014, 6, 4966-4974. [CrossRef]

38. Nssén, J.; Holmberg, J.; Wadeskog, A.; Nyman, M. Direct and indirect energy use and carbon emissions in the production phase of buildings: An input-output analysis. Energy 2007, 32, 1593-1602.

39. Abdallah, T.; Farhat, A.; Diabat, A.; Kennedy, S. Green supply chains with carbon trading and environmental sourcing: Formulation and life cycle assessment. Appl. Math. Model. 2012, 36, 4271-4285. [CrossRef]

(C) 2019 by the authors. Licensee MDPI, Basel, Switzerland. This article is an open access article distributed under the terms and conditions of the Creative Commons Attribution (CC BY) license (http://creativecommons.org/licenses/by/4.0/). 